\title{
Rapid Detection of Monilinia fructicola and Monilinia laxa on Peach and Nectarine using Loop-Mediated Isothermal Amplification
}

\author{
Sara Franco Ortega, ${ }^{1}$ Maria del Pilar Bustos López,,${ }^{1,2}$ Luca Nari, ${ }^{3}$ Neil Boonham, ${ }^{4}$ Maria Lodovica Gullino,,${ }^{1,2}$ \\ and Davide Spadaro ${ }^{1,2, \dagger}$ \\ ${ }^{1}$ Centre of Competence for the Innovation in the Agro-environmental Sector-AGROINNOVA, University of Turin, via Paolo \\ Braccini 2, I-10095 Grugliasco, TO, Italy \\ ${ }^{2}$ Department of Agricultural, Forestry and Food Sciences, University of Torino, via Paolo Braccini 2,I-10095 Grugliasco, TO, \\ Italy \\ ${ }^{3}$ AGRION, Fondazione per la Ricerca l'Innovazione e lo Sviluppo Tecnologico dell'Agricoltura Piemontese, 12030 Manta (Cn), \\ Italy \\ ${ }^{4}$ FERA Sand Hutton, York, United Kingdom
}

\begin{abstract}
Monilinia laxa and M. fructicola are two causal agents of brown rot, one of the most important diseases in stone fruit. Two species cause blight on blossoms and twigs and brown rot on fruit in pre- and postharvest. Both species are distributed worldwide in North and South America, Australia, and Japan. In Europe, M. laxa is endemic, while M. fructicola was introduced in 2001 and it is now widespread in several countries. Currently, both species coexist in European stone fruit orchards. Monilinia spp. overwinter in cankers and mummified fruit. Mummy monitoring during winter permits growers to understand which species of Monilinia will be prevalent in an orchard during the following season, permitting planning of an appropriate crop protection. Traditionally, the identification has been carried out using morphological features and even with polymerase

The loop-mediated amplification (LAMP) assays were validated on some isolates of Monilinia spp. coming from the mummy monitoring according to the international European and Mediterranean Plant Protection Organization standard (PM7/98), taking into account specificity, sensitivity, repeatability, and reproducibility. The sensitivity of both assays was checked by monitoring (at different time points) two nectarine varieties artificially inoculated and stored at two different temperatures. The reliability of both LAMP assays against the quantification of the inoculum was compared with previously published quantitative PCR assays. Both LAMP methods were able to detect a low number of cells. These LAMP methods could be a useful tool for monitoring brown rot causal agents in the field and during postharvest.
\end{abstract} chain reaction (PCR)-based assays that requires time and well-equipped laboratories. In this study, two isothermal-based methods were designed to identify these pathogens in a faster way than using traditional methods.
Keywords: brown rot, field, LAMP, molecular diagnostics, nectarine, peach, Prunus persica, techniques
Monilinia laxa (Aderh. \& Ruhland) Honey, M. fructicola (G. Winter) Honey, M. fructigena Honey, and Monilia polystroma G. Leeuwen are the main agents of brown rot, one of the most important diseases in Prunus, Malus, and Pyrus spp. (Batra 1991).

Brown rot is particularly serious in peach and nectarine production by causing blossom and twig blights and brown rot on the fruit at preharvest, harvest, and postharvest (Hong et al. 1997). Brown rot losses can reach $90 \%$, including the harvest and postharvest stages (Hong et al. 1997, 1998). However, the postharvest stage is the most critical one, due to the optimal environment for Monilinia growth (Eckert and Ogawa 1988; Harvey 1978).The most important and widespread species on peach and nectarine are M. laxa and M. fructicola.

Current address of N. Boonham: IAFRI, Newcastle University, Newcastle upon Tyne, NE1 7RU, United Kingdom.

${ }^{\dagger}$ Corresponding author: D. Spadaro; davide.spadaro@unito.it

Funding: The research leading to these results has received funding from the European Union's Horizon 2020 Framework Programme under grant agreement number 634179 "Effective Management of Pests and Harmful Alien Species-Integrated Solutions" (EMPHASIS).

*The $\boldsymbol{e}$-Xtra logo stands for "electronic extra" and indicates that one supplementary figure and two supplementary tables are published online.

The author(s) declare no conflict of interest.

Accepted for publication 7 April 2019.

(c) 2019 The American Phytopathological Society
M. fructicola was originally identified in North and South America, Australia, and Japan (Smith et al. 1997) and was introduced into Europe (France) on peach in 2001 (Lichou et al. 2002). This pathogen is now spread throughout Europe, with reports in Austria (OEPP/ EPPO 2002), Hungary, and Spain on peach (De Cal et al. 2009); Italy on nectarine (Pellegrino et al. 2009); Germany on blackberry and plum (Hinrichs-Berger and Müller 2010); Slovenia on peach (Munda and Viršček Marn 2010); and Poland on apple, pear, and plum (Poniatowska et al. 2013). In 2005, M. fructicola was included in the A2 European and Mediterranean Plant Protection Organization (EPPO) list of quarantine organisms due to the high yield losses reported on peach, apricot, and nectarine in Europe (EFSA PLH 2011). On the other hand, M. laxa is a quarantine pathogen in China and in some parts of North America (Martini and Mari 2014) and was the most prevalent species in Europe until the introduction of $M$. fructicola. Currently, both species coexist in European stone fruit orchards (Villarino et al. 2013).

M. fructigena, instead, is more prevalent in pome fruit and has a low incidence in stone fruit (Martini and Mari 2014). M. polystroma, morphologically similar to $M$. fructigena, was initially identified in Japan (Côté et al. 2004) and has been introduced in Europe, with reports in apple in Hungary (Petróczy and Palkovics 2009) and Croatia (Di Francesco et al. 2015), apricot in Switzerland (Hilber-Bodmer et al. 2012), and peach in Italy (Martini et al. 2014). However, this species is less aggressive and less prevalent, similar to other minor species such as M. numecola and M. tunnanensis (Cox et al. 2018).

In the United States, the stone fruit market has an annual value of approximately $\$ 4.4$ billion (Cox et al. 2018). Brown rot is mainly caused by $M$. fructicola, the most predominant in stone fruit, while M. laxa is present in some areas of North America with lower 
incidence (Cox et al. 2018). However, M. laxa causes important losses due to development of blossom and shoot blights on almond, apricot, nectarine, and cherry (Cox et al. 2011).

Monilinia spp. overwinter in cankers on branches and on the mummified fruit remaining from one year to the next one. Mummy monitoring during winter permits an understanding of which species of Monilinia will be prevalent in an orchard during the following season, allowing growers to plan appropriate crop protection. Ascospores produced on the apothecia of infected mummified fruit are an important source of inoculum that causes primary infections or blossom blights in the early spring (Tate and Wood 2000).

Due to the importance of brown rot caused by Monilinia spp., intensive disease management is key to reduce blossom blight during spring and to reduce the risk of fruit infection. Different sensitivity to fungicides such as benzimidazoles and dicarboximides (Chen et al. 2013; Egüen et al. 2016) has been reported for different species of Monilinia. The use of fungicides during preharvest is the most common measure used to control the incidence of pre- and postharvest brown rot (Eckert and Ogawa 1988; Thomidis et al. 2009); however, the decision about the optimal moment for chemical control is based on forecasting models. Requests to reduce the use of fungicides is boosting the development of alternative crop protection strategies (Spadaro and Droby 2016), including biocontrol agents (Banani et al. 2015; Larena et al. 2005; Zhang et al. 2010) or natural substances (Lopez-Reyes et al. 2013; Mari et al. 2008; Santoro et al. 2018).

A correct identification of the species of Monilinia may improve crop protection. Fungal isolation and micromorphological analysis are necessary to identify the species of Monilinia but morphological features may vary depending on the incubation media and conditions, making difficult an accurate species-specific identification (Byrde and Willetts 1977; Lane 2002). In addition, micromorphological identification requires a long incubation period that is critical for decision making (OEPP/EPPO 2009). Different assays based on polymerase chain reaction (PCR) amplification of ribosomal DNA internal transcribed spacer (ITS) region (Ioos and Frey 2000), random amplified polymorphic DNA (Boehm et al. 2001; Côté et al. 2004), PCR with sequence-characterized amplified region (SCAR) primers (Hughes et al. 2000), microsatellites using a nested PCR (Boehm et al. 2001; Ma et al. 2003), or quantitative PCR (qPCR) (Guinet et al. 2016; Van Brouwershaven et al. 2009; Wang et al. 2018) have been developed to differentiate the species of Monilinia. However, these methods are time consuming and require transport to a diagnostics laboratory, which delays the decision making process.

The loop-mediated isothermal amplification (LAMP) assay was demonstrated to be a specific, sensitive, and reliable tool for fungal identification in routine diagnostics (Franco Ortega et al. 2018b). The LAMP reaction is an isothermal DNA amplification method with an enzyme copying the target region faster than other PCRbased methods, while avoiding the use of thermal cycling (Nagamine et al. 2002; Notomi et al. 2000). The enzyme is also robust; thus, complex DNA extraction is not required to perform the LAMP assay, which is not affected by inhibitors. The greatest advantage of the LAMP assay is the possibility of using batterypowered platforms such as Genie II or Genie III (Optigene, Horsham, U.K.), which make the LAMP a suitable diagnostic tool for direct detection in the field or packinghouse, or during transport and storage stages.

The aim of the present study was to monitor the occurrence of the emerging pathogen $M$. fructicola and other Monilinia spp. in peach and nectarine orchards during the first four consecutive years of occurrence in Italy. Mummy monitoring during winter permits the planning of an appropriate crop protection strategy against brown rot in the following growing season. A collection of isolates of Monilinia spp. was created, by isolating mummies harvested at the end of the winter season from peach and nectarine. The strains were identified morphologically and with molecular tools. The collection constituted the basis for developing two LAMP assays, one for M. fructicola and the other for M. laxa, the two main species of Monilinia. The molecular assays were validated on a selection of isolates from the mummy collection and on inoculated nectarine fruit.

\section{Materials and Methods}

Pathogen isolation. Forty-six peach and nectarine fields (Supplementary Table S1) were monitored during the winter seasons from 2008-09 to 2011-12 to verify the occurrence of M. fructicola and of other species of Monilinia. The monitoring was carried out on 20 cultivars of peach and nectarine: Alitop, Amiga, Big Top, Caldesi, Diamond Ray, Elegant Lady, Firebrite, Fire Top, Fire Sweet Red, Maeba Top, Nectaross, Orion, Red Valley, Rome Star, Royal Glory, Sweet Lady, Stark Red Gold, Vista Rich, Venus, and V3. Twentyfive mummified fruit, when present, were collected from each orchard, disinfected in a sodium hypochlorite $(1 \%)$ solution, rinsed under tap water, and dried. Small pieces of infected material were placed on potato dextrose agar (PDA; Sigma-Aldrich) to isolate the pathogen. The samples were grown at 23 to $25^{\circ} \mathrm{C}$ for 4 days. Single-spore cultures of each Monilinia isolate were obtained and stored in $60 \%$ glycerol at $-80^{\circ} \mathrm{C}$. The isolates were stored at the Agroinnova microorganism collection (University of Turin, Italy). For the development of the LAMP assays, in addition to the isolates of Monilinia spp. coming from field monitoring, some Monilinia spp. from the FERA collection (York, United Kingdom) and two isolates of $M$. polystroma provided by the University of Bologna were used.

Fungal isolates and DNA extraction. Single-spore isolates listed in Table 1 were grown on PDA for 10 days at room temperature. Mycelium was collected and the total genomic DNA was extracted with the E.Z.N.A. fungal DNA minikit (OMEGA Bio-Tek), according to the manufacturer's instructions. The DNA concentration of each isolate was measured using a Nanodrop 1000 (Thermo Fisher) and the concentration of DNA was adjusted at 1 to $50 \mathrm{ng} / \mu \mathrm{l}$. A multiplex PCR developed by Côté et al. (2004) with the primers listed in Supplementary Table S2 was used to identify all of the samples obtained during the monitoring. Fungal species identification was confirmed with the primers designed by Hughes et al. (2000), including the primer ITS1 for $M$. fructigena and the primers described by Gell et al. (2007). Amplified products were checked on $1.5 \%$ agarose gel stained with ethidium bromide.

Crude extraction method from peach. DNA was extracted from artificially inoculated peach using a crude extraction method to avoid the use of long and complex procedures. The crude extraction was based on the procedure described by Chomczynski and Rymaszewski (2006) and Tomlinson et al. (2010a). Alkaline polyethylene glycol (PEG) buffer $(1 \mathrm{ml})$, composed of $20 \mathrm{mM} \mathrm{KOH}$ at $\mathrm{pH} 13.5$, with PEG at $50 \mathrm{~g} \mathrm{liter}^{-1}$ (average Mn 4,600), with one ball bearing (7/16-in. stainless-steel 316 GD Spheric; Trafalgar Ltd.) in a 5-ml tube, was used for the crude extraction by adding 1 to $2 \mathrm{~g}$ of the inoculated peach material (adding the skin and flesh of the inoculated point, cut by a sterile scalpel). Samples were manually shaken for $1 \mathrm{~min}$. The solution was 10 -fold diluted to use in the LAMP reaction. The peach genomic DNA was also obtained in parallel with the E.Z.N.A. Plant DNA kit (OMEGA Bio-Tek) to compare the results from both DNA extraction methods.

LAMP primer design. Six LAMP primers, including two external primers (F3 and B3), two internal primers (FIP [F1c+ F2] and BIP [B1c+B2]), and two loop primers (Floop and Bloop), were designed from $M$. fructicola and M. laxa sequences according to the method described by Notomi et al. (2000). The LAMP primers for $M$. fructicola were designed on an intron in the cytochrome b, associated with quinone outside inhibitor fungicide resistance, present in M. fructicola (GenBank accession number GQ304941.1) but absent in other Monilinia spp. (Luo et al. 2010). The primers for M. laxa were designed on a genomic sequence identified as a SCAR marker by Gell et al. (2007) (GenBank accession number EF207417.1). All primers were manually designed, taking into account the annealing temperature. Possible hairpin and secondary structures were checked using the OligoCalc program (http://biotools.nubic.northwestern. edu/OligoCalc.html), while possible interactions between primers was controlled using the Multiple Primer Analyzer (Thermo 
Scientific; https://www.thermofisher.com/us/en/home/brands/thermoscientific/molecular-biology/molecular-biology-learning-center/ molecular-biology-resource-library/thermo-scientific-web-tools/multipleprimer-analyzer.html). High-performance liquid chromatographypurified primers were synthesized by Eurofins and both LAMP assays are available in kit format from OptiGene Ltd. (http://www.optigene. co.uk). BLASTn analysis of the F1c and B1c of both primers was performed to check possible cross-reactivity in silico.

LAMP assay. The LAMP reaction $(25 \mu \mathrm{l})$ contained each external primer (F3 and B3) at $200 \mathrm{nmol} /$ liter, each internal primer (FIP and $\mathrm{BIP})$ at $2 \mu \mathrm{mol} / \mathrm{liter}$, each loop primer at $1 \mu \mathrm{mol} / \mathrm{liter}$, and $1 \times$ Isothermal Mastermix ISO-004 (OptiGene Ltd.) with $1 \mu \mathrm{l}$ of the pure DNA or the crude extractions. A Genie II instrument (OptiGene Ltd.) and a StepOne (Applied Biosystems) was used to carry out the LAMP tests. The program conditions were $45 \mathrm{~min}$ at $65^{\circ} \mathrm{C}$ and a measure of the annealing temperature from 95 to $70^{\circ} \mathrm{C}$, with a reduction of $0.05^{\circ} \mathrm{C} / \mathrm{s}$. The StepOne was programmed as described previously by Franco Ortega et al. (2018a). A negative control with water and a positive control with the pure DNA of the target were included in each assay. The COX assay described by Tomlinson et al. (2010b) was applied as internal control to verify whether the plant DNA from the samples that produced negative results with the LAMP assays for M. fructicola and M. laxa could be amplified.

Validation of the LAMP assays. The LAMP assays were validated according to the international standard EPPO PM 7/98, taking into consideration specificity, sensitivity, repeatability, and reproducibility. The specificity of the assays was checked in triplicate using an inclusivity-exclusivity panel of the target and nontarget Monilinia spp., as well as other common pathogens of stone fruit. The sensitivity was tested on 10-fold serial dilutions of the DNA from one isolate of $M$. fructicola (isolate MSR38) and one isolate of M. laxa (isolate 1406), with four replicates of each dilution. The extraction and the LAMP assays were performed on different days with different machines (Genie II and StepOne) by three members of the lab staff to evaluate the reproducibility. The reliability of both LAMP assays was confirmed in parallel with a qPCR assay on two cultivars of nectarine, using three biological replicates and three technical replicates for each assay.

Artificial inoculation and LAMP assay on fruit. Amiga and Fire Top nectarine fruit were inoculated with $M$. fructicola MSR2 and $M$. laxa 1506 . Healthy nectarine fruit were disinfected by submerging in $2 \%$ hypochlorite ( $\mathrm{vol} / \mathrm{vol})$ solutions before being wiped with distilled water and air dried. The fruit inoculation was performed in artificial wounds ( $2 \mathrm{~mm}$ in diameter and $4 \mathrm{~mm}$ deep) using $10 \mu \mathrm{l}$ of the spore suspension $\left(10^{5}\right.$ conidia/ml $)$ prepared from 10-day-old Monilinia cultures grown on PDA. The fruit were stored at 18 or $4^{\circ} \mathrm{C}$. The DNA from the inoculation region of the fruit was used in the crude extraction method and the E.Z.N.A. Plant DNA kit. The quantity of the fruit tissue of each nectarine used in each extraction was measured to calculate the number of cells present in the sample. The LAMP assay was carried out with the crude extraction method at 2,4 to $5,7,9$, and 11 to 12 days postinoculation (dpi) for the nectarine stored at $18^{\circ} \mathrm{C}$ and at 2,4 to $5,7,9,11$ to 12,14 and 16 dpi for the nectarine stored at $4{ }^{\circ} \mathrm{C}$. Sampling times were 4 and 11 dpi for Amiga and 5 and 12 dpi for Fire Top. The fruit symptoms were also scored using the following disease index: $0=$ no evident symptoms, $1=$ brown rot less than $1 \mathrm{~mm}$ in diameter, $2=$ brown $\operatorname{rot} 1$ to $3 \mathrm{~mm}$ in diameter, $3=$ brown rot 1 to $2 \mathrm{~cm}$ in diameter, $4=$ at least half of the fruit surface presented brown rot, and $5=$ mummified fruit. The disease severity was calculated using the average of three replicates (the same three nectarine fruit selected randomly from the inoculated batch and posteriorly used for both DNA extractions). Samples prior to inoculation were used in both LAMP and qPCR analysis as negative controls.

Real-time PCR. The primers designed by Hughes et al. (2000), Mcf-F1 and Mfc-R1 specific for M. fructicola and MI-Mfg-F2 and MI-Mfc-R1 specific for M. laxa, were used to quantify the number of cells present in the samples. The $25-\mu 1$ reactions were carried out using $1 \times$ Power SYBR Green PCR Master Mix (Applied Biosystems), $120 \mathrm{nM}$ each primer, and $1 \mu \mathrm{l}$ of the peach genomic DNA extracted using the commercial kit. The amplification was carried out using the following protocol: $95^{\circ} \mathrm{C}$ for $10 \mathrm{~min}$ and 40 cycles of $15 \mathrm{~s}$ at $95^{\circ} \mathrm{C}, 1 \mathrm{~min}$ at $60^{\circ} \mathrm{C}$, and $45 \mathrm{~s}$ at $72^{\circ} \mathrm{C}$ in a OneStep Plus Real-Time PCR system (Applied Biosystems). A standard curve was performed using $M$. fructicola MSR2 and M. laxa 1506 ranging from $9.4 \mathrm{ng} / \mu \mathrm{l}$ to $9.4 \mathrm{fg} / \mu \mathrm{l}$. A positive control with DNA extracted from cultured pathogen and a negative control of water were included in each run. The quantity of DNA present in the sample was calculated according to the standard curve measures, while the number of cells was estimated using the M. fructicola genome weight $(0.000048 \mathrm{ng}$; https://www.ncbi.nlm.nih.gov/Traces/wgs/?val=NGKE01\#contigs) with the formula number of cells per microliter = DNA quantity/ 0.000048 (Amaral Carneiro et al. 2017). The amount of fruit used (ranging from $1 \mathrm{~g}$ to $2 \mathrm{~g}$ ) and the elution volume of the extracted DNA were used to calculate the total number of cells.

Analytical specificity and sensitivity assays. The inoculated nectarine ( 24 samples) and 8 negative samples ( 4 for either cultivar) were used to calculate some analytical parameters for both LAMP assays, which were compared with the SYBR Green qPCR of Hughes et al. (2000). Diagnostic sensitivity (DSe) or true-positive rate and analytical specificity (DSp) or true-negative rate were calculated using the formula DSe $=\Sigma \mathrm{TP} /(\Sigma \mathrm{TP}+\mathrm{FN})$ and $\mathrm{DSp}=\Sigma \mathrm{TN} /(\Sigma \mathrm{TN}+\mathrm{FP})$, where TP (true positive) is the number of positive samples in the experiment, TN (true negative) is the number of real negative samples, FN (false negative) is the number of negative samples using the LAMP assay but infected with Monilinia spp., and FP (false positive) represents the positive results using the LAMP assay and naturally free from pathogens (Altman and Bland 1994). The likelihood positive ratio $(\mathrm{LR}+)$ and the likelihood negative ratio (LR-) were calculated according to the ratio between DSe and the FP rate and the FP rate and DSe, respectively, using the calculator tool Diagnostic Test Calculator (http://araw.mede.uic.edu/cgi-bin/testcalc.pl)

\section{Results}

Field monitoring. During the monitoring, 1,889 mummified fruit were harvested (281 in 2008-09, 480 in 2009-10, 542 in 2010-11, and 586 in 2011-12). The number of isolates of the different species of Monilinia were recorded to get the incidence in the orchards: 200 isolates from the mummies of 2008-09, 417 from 2009-10, 396 from 2010-11, and 470 from 2011-12. This monitoring permitted us to identify the evolution over time of the Monilinia spp. from the mummies that were able to cause brown rot in peach and nectarine.

An increase in the occurrence of M. fructicola was shown during the years, from a minimum of $6.2 \%$ during the 2008-09 winter season to a maximum of $49.6 \%$ in the 2011-12 season. On the other hand, the incidence of M. laxa decreased from $91.8 \%$ in 2008-09 to $46.6 \%$ in 2011-12. In the 2011-12 winter season, the incidence of $M$. fructicola overtook the incidence of $M$. laxa. (Fig. 1). The incidence of $M$. fructigena was constantly low and did not vary significantly during the study period, from $2.0 \%$ (2008-09) to $2.7 \%$ (2009-10), 2.1\% (2010-11), and 3.8\% (2011-12).

M. fructicola was more abundant in peach than in nectarine during the winter season 2011-12 (Fig. 2). Among the cultivars analyzed during the last winter season, Fire Top (90\%), Fire Sweet Red (90\%), Rome Star (76.1\%), Diamond Ray (69.1\%), Alitop $(63.35 \%)$, and Nectaross $(61.1 \%)$ showed the highest occurrence of M. fructicola, while the varieties with the highest incidence of M. laxa were Stark Red Gold (100\%), Caldesi (69.2\%), Royal Glory $(66.7 \%)$, and Big Top (56.9\%). The highest incidence of $M$. fructigena was found in the variety Caldesi (30\%) whereas, in the other varieties, the incidence was just $7 \%$.

Variation in the Monilinia spp. present was found in different areas. All samples from three locations (Dronero, Manta, and Piasco in Piedmont, northern Italy) were identified as M. laxa, while M. laxa was not isolated from the samples from Castellar and Scarnafigi. The other areas showed different percentages of $M$. laxa and $M$. fructicola. M. fructigena was present in less than $8 \%$ of the samples tested (Supplementary Fig. S1).

A collection of isolates of Monilinia spp. was created, useful for the development of a new diagnostic method to distinguish the predominant 
species of Monilinia. A significant number of isolates from the monitoring were used in the specificity test of both LAMP assays.

Design and validation of the LAMP assay using DNA from pure culture. The primers for the identification of $M$. fructicola and M. laxa were designed on the cytochrome $\mathrm{b}$ sequence and on the SCAR marker region, respectively, identified by Gell et al. (2007). All primers were checked for lack of secondary structure, self-annealing, or hairpin.

BLASTn analysis of the F1c and B1c regions (primers FIP and BIP) for the detection of $M$. fructicola showed $100 \%$ sequence identity with M. fructicola (GenBank accession number KM610206.1), while the F1c and B1c regions of the FIP and BIP primers for the detection M. laxa had $100 \%$ identity to the sequence of this species (accession number EF207417.1).

Initially, identification of the Monilinia spp. was carried out using the primers designed by Hughes et al. (2000) and Gell et al. (2007). Both PCR analyses confirmed the results of the LAMP assays. The isolates of Monilinia spp. from the monitoring, as well as other isolates, were used to validate the specificity of the LAMP assays, which is reported in Table 1 . The LAMP primers amplified only the targets (M. fructicola and M. laxa), whereas untargeted amplifications were not obtained. The time to positive (Tp) for the M. fructicola LAMP assays ranged from $7 \mathrm{~min} 35 \mathrm{~s}$ to $25 \mathrm{~min}$, with an annealing temperature ranging from 84.06 to $85.54^{\circ} \mathrm{C}$. For the M. laxa LAMP assay, the Tp ranged from $7 \mathrm{~min} 11 \mathrm{~s}$ to $24 \mathrm{~min} 26 \mathrm{~s}$, with an annealing temperature ranging from 81.52 to $85^{\circ} \mathrm{C}$.

The sensitivity testing demonstrated that the $M$. fructicola LAMP assay was able to detect 100 to $999 \mathrm{fg}$ of DNA, while the M. laxa LAMP assay had a lower detection limit of 10 to $99 \mathrm{fg}$ of DNA (Table 2). The assays consistently showed positive results in the three replicates tested, even by changing the machine, the operator, or the day of the test.

In vivo testing. Both LAMP assays were tested on two varieties of nectarine. Brown rot symptoms were visible earlier on Amiga than on Fire Top nectarine at both temperatures. Fire Top nectarine inoculated with M. fructicola and stored at $18^{\circ} \mathrm{C}$ started to exhibit concentric lesions from the inoculation area with evident symptoms of brown rot at 7 dpi (Table 3). In contrast, Amiga nectarine stored at $18^{\circ} \mathrm{C}$ exhibited symptoms at $4 \mathrm{dpi}$ (Table 4). Nectarine inoculated with $M$. fructicola and stored at $4^{\circ} \mathrm{C}$ showed the first symptoms of brown rot at 14 dpi on Fire Top and at 7 dpi on Amiga. Brown rot symptoms were visible earlier by inoculating M. laxa than $M$. fructicola on both varieties.

The LAMP assay for $M$. fructicola was able to detect the presence of the pathogen in both nectarine varieties before the appearance of

Table 1. Specificity testing results of the inclusion-exclusion panel of target and nontarget species

\begin{tabular}{|c|c|c|c|c|c|c|}
\hline \multirow[b]{3}{*}{ Isolate } & \multirow[b]{3}{*}{ Species } & \multirow[b]{3}{*}{ Origin } & \multicolumn{4}{|c|}{ LAMP test (average) ${ }^{a}$} \\
\hline & & & \multicolumn{2}{|c|}{ Monilinia fructicola } & \multicolumn{2}{|c|}{ M. laxa } \\
\hline & & & Tp (min:s) & $\operatorname{Temp}\left({ }^{\circ} \mathrm{C}\right)$ & Tp (min:s) & $\operatorname{Temp}\left({ }^{\circ} \mathrm{C}\right)$ \\
\hline 1326 & M. fructicola & Unknown & $07: 35 \pm 00: 17$ & $84.52 \pm 0.46$ & Negative & Negative \\
\hline C3-29 & M. fructicola & Italy & $11: 05 \pm 01: 57$ & $84.18 \pm 0.16$ & Negative & Negative \\
\hline MSR2 & M. fructicola & Italy & $10: 50 \pm 01: 14$ & $84.07 \pm 0.01$ & Negative & Negative \\
\hline MSR38 & M. fructicola & Italy & $09: 45 \pm 00: 15$ & $84.56 \pm 0.30$ & Negative & Negative \\
\hline MSR47 & M. fructicola & Italy & $08: 00 \pm 00: 30$ & $84.19 \pm 0.08$ & Negative & Negative \\
\hline P164C13-12(1) & M. fructicola & Italy & $09: 25 \pm 01: 15$ & $84.64 \pm 0.74$ & Negative & Negative \\
\hline $\mathrm{c} 1 \mathrm{c} 4$ & M. fructicola & Italy & $10: 05 \pm 00: 48$ & $84.76 \pm 0.79$ & Negative & Negative \\
\hline C14-12 (5) & M. fructicola & Italy & $10: 15 \pm 01: 24$ & $84.27 \pm 0.1$ & Negative & Negative \\
\hline 2603 & M. fructicola & Italy & $10: 20 \pm 00: 23$ & $84.55 \pm 0.41$ & Negative & Negative \\
\hline mus26 & M. fructicola & Italy & $09: 15 \pm 01: 34$ & $84.2 \pm 0.12$ & Negative & Negative \\
\hline $\mathrm{s} 14 \mathrm{cf}$ & M. fructicola & Italy & $09: 55 \pm 01: 36$ & $84.14 \pm 0.06$ & Negative & Negative \\
\hline 953 & M. fructicola & Unknown & $18: 35 \pm 07: 09$ & $84.36 \pm 0.21$ & Negative & Negative \\
\hline 866 & M. fructicola & Unknown & $14: 20 \pm 05: 34$ & 84.520 .36 & Negative & Negative \\
\hline 1371 & M. fructicola & Australia & $10: 35 \pm 00: 23$ & $84.24 \pm 0.12$ & Negative & Negative \\
\hline 853 & M. fructicola & Unknown & $09: 50 \pm 02: 08$ & $84.42 \pm 0.56$ & Negative & Negative \\
\hline 881 & M. laxa & France & Negative & Negative & $07: 30$ & $82.88 \pm 0.45$ \\
\hline 1402 & M. laxa & Italy & Negative & Negative & $09: 20 \pm 00: 31$ & $82.44 \pm 0.18$ \\
\hline 1406 & M. laxa & Italy & Negative & Negative & $10: 15 \pm 00: 40$ & $82.57 \pm 0.26$ \\
\hline 1516 & M. laxa & Italy & Negative & Negative & $18: 45 \pm 04: 01$ & $82.44 \pm 0.24$ \\
\hline 1757 & M. laxa & Italy & Negative & Negative & $09: 10 \pm 01: 02$ & $82.54 \pm 0.25$ \\
\hline 1790 & M. laxa & Italy & Negative & Negative & $07: 40 \pm 00: 31$ & $82.26 \pm 0.03$ \\
\hline 1331 & M. laxa & Italy & Negative & Negative & $13: 30 \pm 02: 23$ & $83.33 \pm 1.66$ \\
\hline 1368 & M. laxa & Australia & Negative & Negative & $10: 35 \pm 00: 09$ & $82.62 \pm 0.25$ \\
\hline 1281 & M. laxa & Italy & Negative & Negative & $10: 35 \pm 01: 57$ & $82.63 \pm 0.18$ \\
\hline Ml1 & M. laxa & Italy & Negative & Negative & $09: 15 \pm 01: 00$ & $83.29 \pm 0.76$ \\
\hline 887 & M. laxa & United Kingdom & Negative & Negative & $17: 50 \pm 04: 48$ & $82.68 \pm 0.74$ \\
\hline 888 & M. laxa & United Kingdom & Negative & Negative & $17: 00 \pm 07: 26$ & $82.86 \pm 0.91$ \\
\hline 890 & M. laxa & United Kingdom & Negative & Negative & $10: 20 \pm 01: 08$ & $83.08 \pm 0.81$ \\
\hline 1369 & M. laxa & Australia & Negative & Negative & $08: 45 \pm 01: 09$ & $82.95 \pm 0.81$ \\
\hline 1370 & M. laxa & Australia & Negative & Negative & $08: 30 \pm 01: 09$ & $82.91 \pm 0.61$ \\
\hline 1767 & M. laxa & Unknown & Negative & Negative & $09: 50 \pm 01: 17$ & $81.97 \pm 0.45$ \\
\hline 1791 & M. fructigena & Unknown & Negative & Negative & Negative & Negative \\
\hline 1756 & M. fructigena & Unknown & Negative & Negative & Negative & Negative \\
\hline 1248 & M. fructigena & Unknown & Negative & Negative & Negative & Negative \\
\hline 1249 & M. fructigena & Unknown & Negative & Negative & Negative & Negative \\
\hline 1515 & M. fructigena & Unknown & Negative & Negative & Negative & Negative \\
\hline 1756 & M. fructigena & Unknown & Negative & Negative & Negative & Negative \\
\hline 48 & M. fructigena & Unknown & Negative & Negative & Negative & Negative \\
\hline \multirow[t]{2}{*}{1760} & M. fructigena & Unknown & Negative & Negative & Negative & Negative \\
\hline & & & & & \multicolumn{2}{|c|}{ (Continued on next page) } \\
\hline
\end{tabular}

${ }^{\mathrm{a}} \mathrm{LAMP}=$ loop-mediated amplification, $\mathrm{Tp}=$ time to positive, and Temp = annealing temperature. 
brown rot symptoms (Table 3 and 4). The Tp ranged from 4 min $33 \mathrm{~s}$ to $15 \mathrm{~min}$ from the DNA of nectarine stored at $18^{\circ} \mathrm{C}$, and ranged from $5 \mathrm{~min} 52 \mathrm{~s}$ to $36 \mathrm{~min}$, with the majority of the positive results between 9 to $13 \mathrm{~min}$, from the DNA of nectarine stored at $4^{\circ} \mathrm{C}$ (Tables 3 and 4). The annealing temperature ranged from 84.35 to $85.18^{\circ} \mathrm{C}$ (Tables 3 and 4).

The M. laxa LAMP assay gave positive results prior to symptom development in both nectarine varieties and at both storage temperatures (Tables 5 and 6). There were differences in the LAMP assay for M. laxa between the varieties: Fire Top nectarine fruit were not positive until 7 dpi at both storage temperatures (Table 5) whereas, in Amiga nectarine, the pathogen was detected at 2 dpi (Table 6). Using the DNA from $M$. laxa-inoculated Amiga nectarine stored at $18^{\circ} \mathrm{C}$, the LAMP assay produced a Tp ranging from $4 \mathrm{~min} 2 \mathrm{~s}$ to $24 \mathrm{~min} 15 \mathrm{~s}$ (Table 6). The Tp of the nectarine stored at $4^{\circ} \mathrm{C}$ ranged from $4 \min 2 \mathrm{~s}$ to $28 \min 12 \mathrm{~s}$. The annealing temperature ranged from 83.15 to $83.55^{\circ} \mathrm{C}$ when all samples were compared (Tables 5 and 6).

Comparison between qPCR and LAMP assay. The numbers of cells present during the experiments were quantified using SYBR Green and the combination of primers obtained by Hughes et al. (2000) (Tables 3, 4, 5, and 6). In order to check the sensitivity of the LAMP assays, the numbers of cells of three nectarine varieties were compared with an average of the disease index of the same nectarine to obtain a real comparison between molecular data and symptoms. The number of cells increased over time, reaching a maximum of 20,000,000 cells for the variety Amiga stored at $18^{\circ} \mathrm{C}$. The number of cells of the nectarine increased day after day, similarly to the disease index. This trend was observed in both varieties (Amiga nectarine inoculated with M. fructicola and M. laxa stored at 18 and $4{ }^{\circ} \mathrm{C}$, respectively, as well as Fire Top inoculated with M. laxa and stored at $18^{\circ} \mathrm{C}$ ); however, the LAMP assay gave reliable detection.

Different results were obtained with the QPCR and the LAMP assays. In the case of $M$. fructicola-inoculated nectarine, both techniques showed positive results for both nectarine varieties at both storage temperatures, with only one exception in which the qPCR was not able to detect any cells (Fire Top nectarine at 2 dpi). However, as observed in Tables 3 and 4, there were significant differences between the number of positives obtained with each technique, with the qPCR being more repeatable.

On the other hand, there were bigger differences between the qPCR and the LAMP assays in detecting M. laxa. In the case of Fire Top nectarine stored at $18^{\circ} \mathrm{C}$ at $2 \mathrm{dpi}$ and at $4^{\circ} \mathrm{C}$ at 2 and $4 \mathrm{dpi}$, fungi were only detected with the qPCR and not with the LAMP (Table 5). However, fungi in Amiga nectarine stored at both temperatures were

Table 1. (Continued from previous page)

\begin{tabular}{|c|c|c|c|c|c|c|}
\hline \multirow[b]{3}{*}{ Isolate } & \multirow[b]{3}{*}{ Species } & \multirow[b]{3}{*}{ Origin } & \multicolumn{4}{|c|}{ LAMP test (average) ${ }^{a}$} \\
\hline & & & \multicolumn{2}{|c|}{ Monilinia fructicola } & \multicolumn{2}{|c|}{ M. laxa } \\
\hline & & & Tp (min:s) & $\operatorname{Temp}\left({ }^{\circ} \mathrm{C}\right)$ & Tp (min:s) & $\operatorname{Temp}\left({ }^{\circ} \mathrm{C}\right)$ \\
\hline 1762 & M. fructigena & Unknown & Negative & Negative & Negative & Negative \\
\hline 1763 & M. fructigena & Unknown & Negative & Negative & Negative & Negative \\
\hline 1765 & M. fructigena & Unknown & Negative & Negative & Negative & Negative \\
\hline 1770 & M. fructigena & Unknown & Negative & Negative & Negative & Negative \\
\hline 1773 & M. fructigena & Unknown & Negative & Negative & Negative & Negative \\
\hline 1718 & M. polystroma & Unknown & Negative & Negative & Negative & Negative \\
\hline 1719 & M. polystroma & Unknown & Negative & Negative & Negative & Negative \\
\hline 1538 & Verticillium albo-atrum & Unknown & Negative & Negative & Negative & Negative \\
\hline 1540 & Colletotrichum truncatum & Unknown & Negative & Negative & Negative & Negative \\
\hline 1542 & Helminthosporium solani & Unknown & Negative & Negative & Negative & Negative \\
\hline 1543 & Cylindrocarpon & Unknown & Negative & Negative & Negative & Negative \\
\hline 1544 & Botryosphaeria berengeriana & Unknown & Negative & Negative & Negative & Negative \\
\hline 1547 & B. laricina & Unknown & Negative & Negative & Negative & Negative \\
\hline 1548 & B. laricina & Unknown & Negative & Negative & Negative & Negative \\
\hline 2692 & Colletotrichum acutatum & Unknown & Negative & Negative & Negative & Negative \\
\hline 92 & Zythia fragariae & Unknown & Negative & Negative & Negative & Negative \\
\hline 221 & G. cingulata/C. acutatum & Unknown & Negative & Negative & Negative & Negative \\
\hline 256 & C. acutatum & Unknown & Negative & Negative & Negative & Negative \\
\hline 308 & Eutypa lata & Unknown & Negative & Negative & Negative & Negative \\
\hline 332 & Macrophoma japonica & Unknown & Negative & Negative & Negative & Negative \\
\hline 452 & Cylindrocarpon & Unknown & Negative & Negative & Negative & Negative \\
\hline 667 & Zythia sp. & Unknown & Negative & Negative & Negative & Negative \\
\hline 668 & Mycosphaerella pinodes & Unknown & Negative & Negative & Negative & Negative \\
\hline 677 & Lambertella corni-maris & Unknown & Negative & Negative & Negative & Negative \\
\hline 931 & Phytophthora fragariae & Unknown & Negative & Negative & Negative & Negative \\
\hline 1138 & C. fragariae & Unknown & Negative & Negative & Negative & Negative \\
\hline 1725 & Rhizopus spp. & Unknown & Negative & Negative & Negative & Negative \\
\hline 2556 & $\begin{array}{l}\text { Phytophthora fragariae } \\
\text { var. fragariae }\end{array}$ & Unknown & Negative & Negative & Negative & Negative \\
\hline 1539 & Alternaria spp. & Unknown & Negative & Negative & Negative & Negative \\
\hline 77 & Penicillium citrinum & Unknown & Negative & Negative & Negative & Negative \\
\hline MCAL & Aspergillus flavus & Unknown & Negative & Negative & Negative & Negative \\
\hline X1 & P. expansum & Unknown & Negative & Negative & Negative & Negative \\
\hline Dpo1 & Diaporthe spp. & Unknown & Negative & Negative & Negative & Negative \\
\hline $\mathrm{Bc}$ & Botrytis cinerea & Unknown & Negative & Negative & Negative & Negative \\
\hline Gun1 & Guignardia & Unknown & Negative & Negative & Negative & Negative \\
\hline Ps & Plasmopora & Unknown & Negative & Negative & Negative & Negative \\
\hline AltAlter & Alternaria alternata & Unknown & Negative & Negative & Negative & Negative \\
\hline
\end{tabular}


detected with the LAMP at all time points but the $\mathrm{qPCR}$ produced negative results in two cases: nectarine stored at $18^{\circ} \mathrm{C}$ at 2 dpi and $4^{\circ} \mathrm{C}$ after 9 dpi (Table 6). The LR+ and LR- of both assays were calculated to check the effectiveness of the LAMP assay in comparison with the qPCR with SYBR Green. In the case of the LAMP assay for M. fructicola, the value of DSp and DSe were 1.0 (100\%), while the DSp and DSe values of the specific primers were $0.88(88 \%)$ and 0.96 (96\%), respectively. The M. laxa LAMP assay showed a DSp value of $0.83(83 \%)$ and a DSe value of $0.67(67 \%)$ compared with the $0.88(0.88 \%)$ and $0.73(73 \%)$ for DSp and DSe values, respectively, of the specific primers.

Taking into consideration the likelihood ratios, the LR+ and LRof $M$. fructicola LAMP assay were infinite, whereas the LR- of the M. laxa LAMP assay was 0.17 and the LR+ was infinite. The same values calculated for the qPCR primers with SYBR Green for $M$. fructicola and M. laxa showed, in both cases, infinite LR+ and LR- of 0.04 and 0.12 , respectively.

\section{Discussion}

The occurrence of Monilinia spp. was monitored during four winter seasons in Italian peach and nectarine orchards for a better understanding of the establishment of the introduced species $M$. fructicola and of the evolution of the species of Monilinia. The results of the mummy monitoring over 4 years helped in understanding the capacity of coexistence of M. laxa and M. fructicola in the same orchards. Since the first report of $M$. fructicola in Europe, the pathogen, listed as an EPPO A2 pathogen due to the damage caused, has spread to different countries. Despite the importance of stone fruit

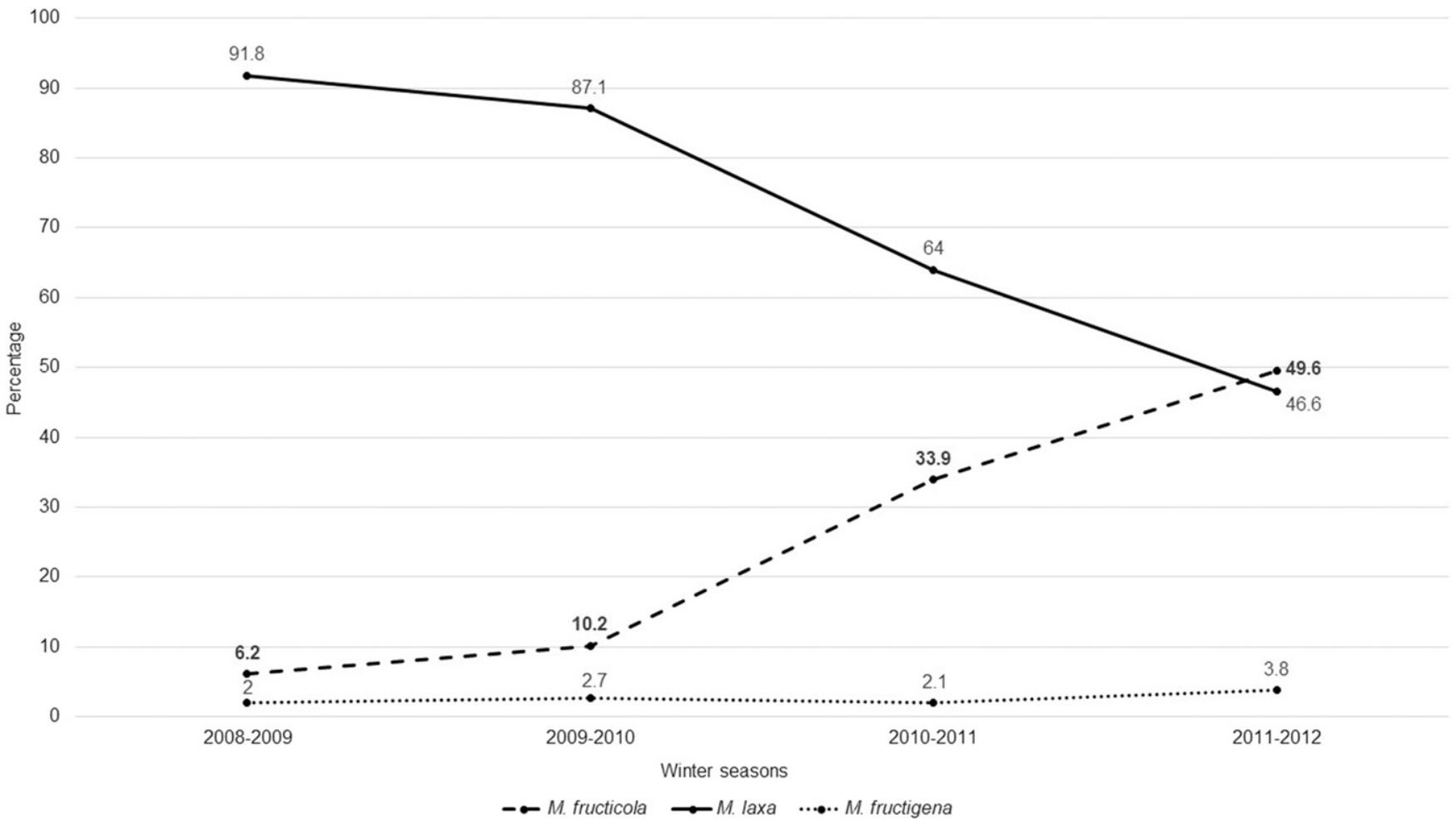

Fig. 1. Incidence of Monilinia spp. (\%) during the monitoring of four winter seasons (2008-09 to 2011-12): Monilinia laxa (solid line), M. fructicola (dashed line), and M. fructigena (dotted line).

A

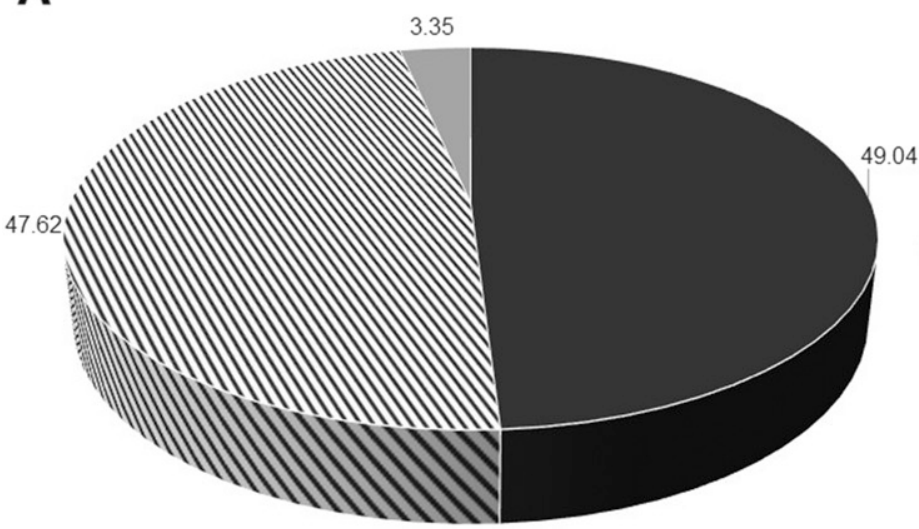

- M. fructicola : M. laxa " M. fructigena
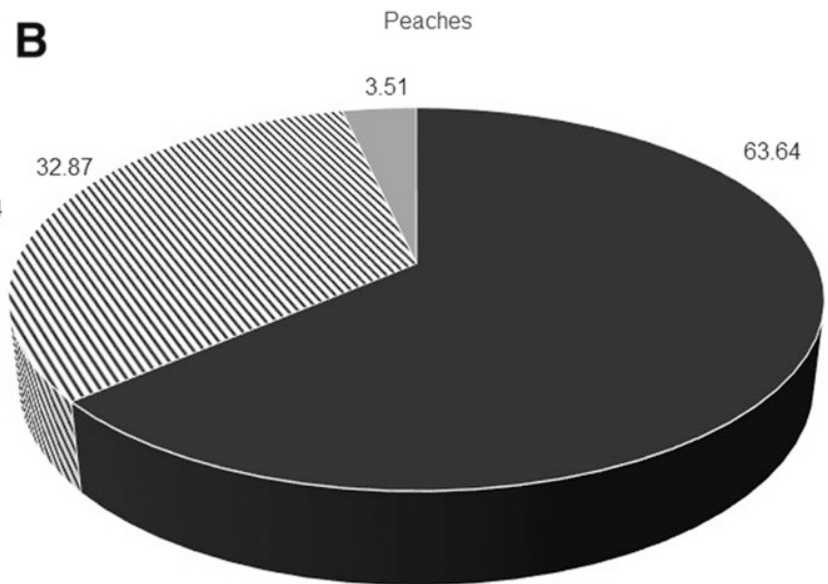

- M. fructicola 、M. laxa " M. fructigena

Fig. 2. Percentage of Monilinia spp. isolated from A, nectarine and B, peach during the winter season 2011-12. 
Table 2. Sensitivity testing of the Monilinia fructicola and M. laxa loopmediated amplification assay reporting the number of replicates amplified out of the total replicates tested ${ }^{\mathrm{a}}$

\begin{tabular}{lccccc}
\hline & \multicolumn{2}{c}{ M. fructicola isolates } & & \multicolumn{2}{c}{ M. laxa isolates } \\
\cline { 2 - 3 } \cline { 5 - 6 } DNA & MSR38 & c14-12 & & $\mathbf{1 4 0 6}$ & $\mathbf{1 7 9 0}$ \\
\hline $1-10 \mathrm{ng}$ & $5 / 5(07: 09)$ & $4 / 4(09: 35)$ & & $5 / 5(11: 49)$ & $4 / 4(08: 26)$ \\
$100-999 \mathrm{pg}$ & $5 / 5(08: 00)$ & $4 / 4(10: 35)$ & & $5 / 5(10: 41)$ & $4 / 4(09: 37)$ \\
$10-99 \mathrm{pg}$ & $5 / 5(09: 21)$ & $4 / 4(11: 45)$ & & $3 / 5(17: 55)$ & $3 / 4(16: 45)$ \\
$1-9.9 \mathrm{pg}$ & $3 / 5(09: 56)$ & $1 / 4(14: 30)$ & & $1 / 5(14: 15)$ & $0 / 4$ \\
$100-999 \mathrm{fg}$ & $0 / 5$ & $0 / 4$ & & $1 / 5(29: 15)$ & $0 / 4$ \\
$10-99 \mathrm{fg}$ & $0 / 5$ & $0 / 4$ & & $0 / 5$ & $0 / 4$ \\
$1-9.9 \mathrm{fg}$ & $0 / 5$ & $0 / 4$ & & $0 / 5$ & $0 / 5$ \\
\hline
\end{tabular}

a Time to positive average of the positive results is shown in parenthesis (min: s). Sensitivity testing was carried out using two different isolates. production in Italy, extensive monitoring activity has not not performed by other authors since the first occurrence (Pellegrino et al. 2009). The geographical region where M. fructicola was first identified in Italy was the focus of this study. M. laxa and $M$. fructicola could produce fruit losses up to $90 \%$ (Hong et al. 1997; Larena et al. 2005) under favorable weather conditions. The losses caused by $M$. fructigena are by far lower, with a relatively low incidence in Italy. In this study, the incidence of $M$. fructicola increased year after year, overtaking the incidence of $M$. laxa in the 2011-12 survey. This suggested a higher fitness of $M$. fructicola and the higher adaptability to the weather conditions of northern Italy.

The estimation of the mummy inoculum and the optimal environmental conditions for disease development should be considered to understand the seasonal variation of the disease and to ensure the timely implementation of a management strategy against brown rot

Table 3. Results of the Monilinia fructicola loop-mediated amplification (LAMP) assay and the quantitative polymerase chain reaction (qPCR) using the primers MI-Mfg-F2 and MI-Mfc-R1 on the DNA obtained from Fire Top nectarine inoculated with M. fructicola and stored at 18 and $4^{\circ} \mathrm{C}^{\mathrm{a}}$

\begin{tabular}{|c|c|c|c|c|c|c|c|}
\hline \multirow[b]{2}{*}{ T, dpi } & \multirow[b]{2}{*}{ DI } & \multicolumn{3}{|c|}{ LAMP assay } & \multicolumn{3}{|c|}{ qPCR assay } \\
\hline & & Tp (min:s) & Pos & Anneal $\left({ }^{\circ} \mathrm{C}\right)$ & $\mathrm{Ct} \pm \mathrm{SD}$ (range) & Pos & Cells/g \\
\hline \multicolumn{8}{|l|}{$18^{\circ} \mathrm{C}$} \\
\hline 2 & 0.00 & $11: 31 \pm 01: 55(09: 02-14: 41)$ & $5 / 9$ & $84.85 \pm 0.07$ & $32.22 \pm 1.03(30.34-33.08)$ & 9/9 & $3,143.8(8,477.9-2,000)$ \\
\hline 5 & 0.00 & $10: 03 \pm 03: 02(04: 33-12: 50)$ & $6 / 9$ & $84.54 \pm 0.1$ & $36.39 \pm 0.58(35.69-37.10)$ & $4 / 9$ & $995.8(1,439-685.3)$ \\
\hline 7 & 0.67 & $10: 56 \pm 00: 10(10: 50-11: 04)$ & $2 / 9$ & $85.18 \pm 0.01$ & $36.06 \pm 2.87(33.24-39.25)$ & $4 / 9$ & $759.7(3,352.9-141.9)$ \\
\hline 9 & 1.00 & $07: 06 \pm 04: 25(06: 33-07: 47)$ & $3 / 9$ & $84.81 \pm 0.14$ & $21.43 \pm 8.96(13.26-36.83)$ & $5 / 9$ & $5.4+06(3.98 \mathrm{E}+08-1,636)$ \\
\hline 12 & 4.00 & $09: 02 \pm 01: 32(07: 05-11: 17)$ & 9/9 & $85.09 \pm 0.1$ & $21.25 \pm 6.84(12.59-30.73)$ & 9/9 & $6.3+06(6 \mathrm{E}+08-42,931)$ \\
\hline 14 & NT & NT & NT & NT & NT & NT & NT \\
\hline 16 & NT & NT & NT & NT & NT & NT & NT \\
\hline \multicolumn{8}{|l|}{$4^{\circ} \mathrm{C}$} \\
\hline 2 & 0.00 & $18: 52 \pm 14: 48(09: 37-35: 57)$ & $3 / 9$ & $84.43 \pm 0.54$ & $33.69 \pm 1.09(32.31-35.30)$ & $7 / 9$ & $1,559.4(3,223-668.4)$ \\
\hline 5 & 0.00 & $12: 13 \pm 08: 21(07: 01-30: 59)$ & $8 / 9$ & $84.56 \pm 0.14$ & Neg & $\mathrm{Neg}$ & Neg \\
\hline 7 & 0.00 & $12: 11 \pm 01: 25(11: 02-15: 00)$ & $6 / 9$ & $85.17 \pm 0.11$ & $38.89 \pm 0.78(38.34-39.44)$ & $2 / 9$ & $259.7(346.5-194.2)$ \\
\hline 9 & 0.00 & $10: 28 \pm 23(10: 12-10: 54)$ & $3 / 9$ & $84.69 \pm 0.17$ & $27.94 \pm 5.23(20.52-33.72)$ & $9 / 9$ & $2.0+05(1 \mathrm{E}+07-9,696)$ \\
\hline 12 & 0.00 & $19: 50 \pm 08: 54(13-36: 56)$ & $4 / 9$ & $84.62 \pm 0.83$ & $33.91 \pm 1.68(32.20-36.51)$ & $9 / 9$ & $6,428.6(1.6+04-1,638.9)$ \\
\hline 14 & 1.33 & $10: 23 \pm 02: 00(09: 08-13: 57)$ & $5 / 9$ & $84.98 \pm 0.09$ & $18.61 \pm 1.71(16-20.49)$ & $6 / 9$ & 7.7E+06 $(3 \mathrm{E}+07-2.8 \mathrm{E}+06)$ \\
\hline 16 & 0.00 & $13: 49 \pm 02: 00(11: 11-17: 22)$ & 9/9 & $84.83 \pm 0.08$ & $33.82 \pm 7.03(23.49-39.23)$ & $4 / 9$ & 2,573.7 (5.9E+06-149.6) \\
\hline
\end{tabular}

a The LAMP assay was performed on the crude extracted DNA while the qPCR was carried out using DNA extracted using a commercial kit at different time points. Abbreviations: $\mathrm{T}=$ storage temperature, $\mathrm{dpi}=$ days postinoculation, $\mathrm{DI}=$ disease index, $\mathrm{Tp}=$ time to positive, $\mathrm{Pos}=$ number of positive, Anneal $=$ anneal ing temperature, $\mathrm{Ct}=$ cycle threshold, $\mathrm{SD}=$ standard deviation, $\mathrm{NT}=$ not tested, and $\mathrm{Neg}=$ negative

Table 4. Results of the Monilinia fructicola loop-mediated amplification (LAMP) assay and the quantitative polymerase chain reaction (qPCR) using the primers MI-Mfg-F2 and MI-Mfc-R1 on the DNA obtained from Amiga nectarine inoculated with $M$. fructicola and stored at 18 and $4^{\circ} \mathrm{C}$ during the time ${ }^{\mathrm{a}}$

\begin{tabular}{|c|c|c|c|c|c|c|c|}
\hline \multirow[b]{2}{*}{ T, dpi } & \multirow[b]{2}{*}{ DI } & \multicolumn{3}{|c|}{ LAMP assay } & \multicolumn{3}{|c|}{ qPCR assay } \\
\hline & & Tp (min:s) & Pos & Anneal $\left({ }^{\circ} \mathrm{C}\right)$ & $\mathrm{Ct} \pm \mathrm{SD}$ (range) & Pos & Cells/g \\
\hline \multicolumn{8}{|l|}{$18^{\circ} \mathrm{C}$} \\
\hline 2 & 0.00 & $12: 11 \pm 01: 25(11: 02-15: 00)$ & $6 / 9$ & $85.17 \pm 0.11$ & $36.11 \pm 1.46(34.58-39.06)$ & $8 / 9$ & $28(62.7-5.9)$ \\
\hline 4 & 1.00 & $08: 18 \pm 02: 02(06: 35-10: 55)$ & $6 / 9$ & $84.67 \pm 0.08$ & $34.23 \pm 2.15(31.99-37)$ & $4 / 9$ & $66.6(216.3-15.5)$ \\
\hline 7 & 3.00 & $08: 22 \pm 01: 38(07: 05-11: 46)$ & $9 / 9$ & $84.95 \pm 0.15$ & $22.99 \pm 6.47(16.68-30.98)$ & $6 / 9$ & $2.2 \mathrm{E}+04(6.2 \mathrm{E}+05-333.9)$ \\
\hline 9 & 4.00 & $08: 09 \pm 00: 50(06: 52-09: 23)$ & $9 / 9$ & $84.67 \pm 0.13$ & $18.61 \pm 1.71(16-20.49)$ & $6 / 9$ & $3.9 \mathrm{E}+05(1.6 \mathrm{E}+06-1.46 \mathrm{E}+06)$ \\
\hline 12 & 5.00 & $09: 51 \pm 02: 00(09: 57-12: 40)$ & 9/9 & $84.35 \pm 0.28$ & $29.88 \pm 3.2426 .75-33.17)$ & 9/9 & $1,048.5(5,435.4-185.4)$ \\
\hline 14 & NT & NT & NT & NT & NT & NT & NT \\
\hline 16 & NT & NT & NT & NT & NT & NT & NT \\
\hline \multicolumn{8}{|l|}{$4^{\circ} \mathrm{C}$} \\
\hline 2 & 0.00 & $14: 20 \pm 04: 19(11: 44-25: 31)$ & $9 / 9$ & $85.0 \pm 0.15$ & $36.85 \pm 1.85(33.93-38.33)$ & $8 / 9$ & $22.8(106.1-10.5)$ \\
\hline 4 & 1.33 & $12: 14 \pm 03: 52(09: 50-12: 28)$ & $6 / 9$ & $84.64 \pm 0.15$ & $30.33 \pm 1.6(28.26-33.51)$ & $9 / 9$ & $497.9(1,482.5-93.6)$ \\
\hline 7 & 0.33 & $12 \pm 01: 18(11: 34-15: 14)$ & $7 / 9$ & $85.00 \pm 0.12$ & $30.19 \pm 2.17(27.81-33.29)$ & $9 / 9$ & $626.7(2,186.9-122.3)$ \\
\hline 9 & 0.00 & $10: 26 \pm 00: 53(09: 22-11: 30)$ & $6 / 9$ & $84.9 \pm 0.08$ & $28.91 \pm 2.8(24.44-32.62)$ & $9 / 9$ & $1,844.3(1.9 \mathrm{E}+04-261.5)$ \\
\hline 12 & 1.00 & $07: 13 \pm 00: 02 \quad 06: 43-07: 426$ & $6 / 9$ & $84.73 \pm 0.14$ & $34.04 \pm 4.03(28.15-39.05)$ & $8 / 9$ & $123.8(2,747.3-8.9)$ \\
\hline 14 & 0.67 & $08 \pm 02: 03$ 06:17-11:29 & $9 / 9$ & $84.7 \pm 0.15$ & $28.15 \pm 5.98(18.6-33.39)$ & $9 / 9$ & $2,754(4.2 \mathrm{E}+05-174.4)$ \\
\hline 16 & 1.67 & $07: 25 \pm 01: 52(05: 52-11: 15)$ & $9 / 9$ & $84.72 \pm 0.19$ & $23.7 \pm 4.18(19.43-30.80)$ & 9 & $2.8 \mathrm{E}+04(2.7 \mathrm{E}+05-681.3)$ \\
\hline
\end{tabular}

${ }^{a}$ The LAMP assay was performed on the crude extracted DNA while the qPCR was carried out using DNA extracted using a commercial kit at different time points. Abbreviations: $\mathrm{T}=$ storage temperature, $\mathrm{dpi}=$ days postinoculation, $\mathrm{DI}=$ disease index, $\mathrm{Tp}=$ time to positive, $\mathrm{Pos}=$ number of positive, Anneal $=$ anneal ing temperature, $\mathrm{Ct}=$ cycle threshold, $\mathrm{SD}=$ standard deviation, and $\mathrm{NT}=$ not tested. 
(Luo and Michailides 2001a; Luo et al. 2001). The monitoring of mummies during winter permits growers to plan an appropriate crop protection strategy, which depends on the species of Monilinia present in the orchard. An Integrated Pest Management approach is suggested by EFSA PLH (2011) in order to effectively control brown rot and blossom blight, focusing on reducing the inoculum of Monilinia spp. in the field and, therefore, the risk of infection (Luo and Michailides 2001b). The significance of the mummies as an important inoculum source was confirmed during the survey. Therefore, removal and destruction of the fruit mummies is a key aspect of the sanitation process, especially given the diffusion speed of brown rot in orchards.

During postharvest, the incidence of brown rot is associated with the incidence of Monilinia spp. in the orchard. Any delay on the application of control measures for Monilinia spp. can cause losses of over $50 \%$, particularly during postharvest, but yield losses can be reduced if correct control measures are applied in a timely fashion (Margosan et al. 1997). However, some of the measures developed to reduce brown rot have been demonstrated to be species dependent
(Lopez-Reyes et al. 2013; Mari et al. 2012), making a precise identification of the causal agent of brown rot necessary. Until now, no LAMP tests have been developed to directly check the presence of Monilinia spp. on fruit; therefore, the methods described in this study could help growers to control the presence of brown rot in peach by supporting the choice of the correct control measures before harvesting and during storage.

One of the biggest drawbacks of the PCR-based methods is the inhibition of the reaction by some components of plant tissue, which results in false-negative results (Wilson 1997); therefore, most PCR-based methods involve long and complex DNA extraction methods. As an alternative, the LAMP assays for the detection of M. fructicola and M. laxa were validated using a crude extraction method, which is simpler and was shown to be reliable and effective in the detection of both pathogen species.

The validation of the assays was carried out according to the international standard published by EPPO (PM7/98). A significant number of isolates from the monitoring were used to validate the

Table 5. Results of the Monilinia laxa loop-mediated amplification (LAMP) assay and the quantitative polymerase chain reaction (qPCR) using the primers MI-Mfg-F2 and MI-Mfc-R1 on the DNA obtained from the Fire Top nectarine inoculated with M. laxa and stored at 18 and $4^{\circ} \mathrm{C}$ during the time ${ }^{\mathrm{a}}$

\begin{tabular}{|c|c|c|c|c|c|c|c|}
\hline \multirow[b]{2}{*}{ T, dpi } & \multirow[b]{2}{*}{ DI } & \multicolumn{3}{|c|}{ LAMP assay } & \multicolumn{3}{|c|}{ qPCR assay } \\
\hline & & Tp (min:s) & Pos & Anneal $\left({ }^{\circ} \mathrm{C}\right)$ & $\mathrm{Ct} \pm \mathrm{SD}$ (range) & Pos & Cells/g \\
\hline \multicolumn{8}{|l|}{$18^{\circ} \mathrm{C}$} \\
\hline 2 & 0.00 & Neg & Neg & Neg & $36.36 \pm 2.36(34.69-38.02)$ & $2 / 9$ & $104.0(317.4-71.1)$ \\
\hline 4 & 1.33 & Neg & $\mathrm{Neg}$ & Neg & Neg & Neg & Neg \\
\hline 7 & 2.33 & $12: 02 \pm 01: 39(10: 34-14: 23)$ & $4 / 9$ & $83.55 \pm 0.12$ & $36.52 \pm 0.84(35.55-37.03)$ & $3 / 9$ & $186.9(358.4-137.7)$ \\
\hline 9 & 4.00 & $07: 52 \pm 00: 56(06: 45-09: 44)$ & $9 / 9$ & $83.47 \pm 0.24$ & $20.66 \pm 1.15(19-22.09)$ & $9 / 9$ & $2.3 \mathrm{E}+07(6 \mathrm{E}+07-9.9 \mathrm{E}+06)$ \\
\hline 11 & 5.00 & $11: 13 \pm 03: 27(08: 29-12: 39)$ & $6 / 9$ & $83.15 \pm 0.4$ & $29.37 \pm 3.52(27.17-37.11)$ & 9/9 & $15 \mathrm{E}+05(6.7 \mathrm{E}+05-418)$ \\
\hline 14 & NT & NT & NT & NT & NT & NT & NT \\
\hline 16 & NT & NT & NT & NT & NT & NT & NT \\
\hline \multicolumn{8}{|l|}{$4^{\circ} \mathrm{C}$} \\
\hline 2 & 0.00 & $\mathrm{Neg}$ & Neg & $\mathrm{Neg}$ & $36.11 \pm 1.08(34.91-37.01)$ & $3 / 9$ & $126.3(282.6-139.6)$ \\
\hline 4 & 1.33 & Neg & Neg & Neg & $34.45 \pm 1.38(33.47-35.42)$ & $2 / 9$ & $671.0(1,289.5-403.9)$ \\
\hline 7 & 0.00 & $12: 46$ & $1 / 9$ & 83.55 & $38.32 \pm 0.89(37.69-38.95)$ & $2 / 9$ & $73.5(112.1-38.2)$ \\
\hline 9 & 0.00 & $13: 40 \pm 08: 25(08: 04-28: 12)$ & $5 / 9$ & $83.26 \pm 0.15$ & $31.38 \pm 1.3(29.47-32.55)$ & $9 / 9$ & $1.7 \mathrm{E}+04(6.1 \mathrm{E}+04-9,168.9)$ \\
\hline 11 & 1.00 & $09: 27 \pm 00: 22(09: 04-09: 55)$ & $6 / 9$ & $83.29 \pm 0.16$ & $24.31 \pm 6.66(19.38-34.18)$ & $6 / 9$ & $2.3 \mathrm{E}+06(6 \mathrm{E}+07-3,084.4)$ \\
\hline 14 & 1.33 & $06: 59 \pm 04: 11(04: 02-11: 47)$ & $4 / 9$ & $83.44 \pm 0.07$ & $27.88 \pm 2.23(27.25-30.26)$ & $8 / 9$ & $5.3 \mathrm{E}+04(2.7 \mathrm{E}+05-1,2 \mathrm{E}+04)$ \\
\hline 16 & 1.33 & $08: 07 \pm 00: 21(07: 46-08: 28)$ & $3 / 9$ & $83.44 \pm 0.08$ & $26.6 \pm 9.99(17.52-38.18)$ & $7 / 9$ & $1.3 \mathrm{E}+05(1.8 \mathrm{E}+08-54.3)$ \\
\hline
\end{tabular}

a The LAMP assay was performed on the crude extracted DNA while the qPCR was carried out using DNA extracted using a commercial kit at different time points. Abbreviations: $\mathrm{T}=$ storage temperature, $\mathrm{dpi}=$ days postinoculation, $\mathrm{DI}=$ disease index, $\mathrm{Tp}=$ time to positive, $\mathrm{Pos}=$ number of positive, Anneal $=$ annealing temperature, $\mathrm{Ct}=$ cycle threshold, $\mathrm{SD}=$ standard deviation, $\mathrm{Neg}=$ negative, and $\mathrm{NT}=$ not tested.

Table 6. Results of the Monilinia laxa loop-mediated amplification (LAMP) assay and the quantitative polymerase chain reaction (qPCR) using the primers MI-Mfg-F2 and MI-Mfc-R1 on the DNA obtained from Amiga nectarine inoculated with $M$. laxa and stored at 18 and $4^{\circ} \mathrm{C}$ during the time ${ }^{\mathrm{a}}$

\begin{tabular}{|c|c|c|c|c|c|c|c|}
\hline \multirow[b]{2}{*}{ T, dpi } & \multirow[b]{2}{*}{ DI } & \multicolumn{3}{|c|}{ LAMP assay } & \multicolumn{3}{|c|}{ qPCR assay } \\
\hline & & Tp (min:s) & Pos & Anneal $\left({ }^{\circ} \mathbf{C}\right)$ & $\mathrm{Ct} \pm \mathrm{SD}$ (range) & Pos & Cells/g \\
\hline \multicolumn{8}{|l|}{$18^{\circ} \mathrm{C}$} \\
\hline 2 & 0.00 & $12: 29 \pm 05: 09(09: 00-24: 15)$ & $8 / 9$ & $83.43 \pm 0.14$ & Neg & Neg & Neg \\
\hline 4 & 1.33 & $08: 44 \pm 01: 44(07: 16-10: 41)$ & $9 / 9$ & $83.35 \pm 0.2$ & $32.4502 \pm 3.832(29.19-39.92)$ & $7 / 9$ & $81.2(717.9-0.6)$ \\
\hline 7 & 3.67 & $08: 48 \pm 02: 44(08: 02-13: 20)$ & $9 / 9$ & $83.25 \pm 0.21$ & $28.5379 \pm 4.06(22.81-32.04)$ & $9 / 9$ & $997.1(4.6 \mathrm{E}+04-96)$ \\
\hline 9 & 4.00 & $07: 16 \pm 02: 28(04: 02-10: 00)$ & $9 / 9$ & $83.35 \pm 0.11$ & $29.3679 \pm 0.41(28.97-29.79)$ & $3 / 9$ & $666.9(870-502.9)$ \\
\hline 12 & 5.00 & $08: 06 \pm 01: 13(06: 40-09: 50)$ & $9 / 9$ & $83.27 \pm 0.18$ & $25.62 \pm 4.09(20.21-31.58)$ & $9 / 9$ & $8,151.5(3 \mathrm{E}+05-152)$ \\
\hline 14 & NT & $\mathrm{NT}$ & NT & NT & NT & NT & NT \\
\hline 16 & NT & NT & NT & NT & NT & NT & NT \\
\hline \multicolumn{8}{|l|}{$4^{\circ} \mathrm{C}$} \\
\hline 2 & 0.00 & $11: 12 \pm 01: 46(09: 41-13: 58)$ & $2 / 9$ & $83.48 \pm 0.1$ & $38.7275 \pm 1.07(37.11-39.93)$ & $5 / 9$ & $1.3(3.8-0.6)$ \\
\hline 4 & 0.33 & $11: 30 \pm 03: 17(06: 59-20: 20)$ & $5 / 9$ & $83.28 \pm 0.16$ & $30.9794 \pm 2.08(27.77-33.81)$ & $9 / 9$ & $188(1,606.1-28.3)$ \\
\hline 7 & 0.67 & $10: 54 \pm 02: 17(08: 23-11: 55)$ & $5 / 9$ & $83.28 \pm 0.17$ & $25.9199 \pm 6.02(17.79-31.35)$ & $9 / 9$ & $7,481.7(1.7 \mathrm{E}+06-198.5)$ \\
\hline 9 & 1.00 & $08: 55 \pm 03: 21(07: 38-16: 29)$ & $9 / 9$ & $82.89 \pm 1.66$ & Neg & $\mathrm{Neg}$ & Neg \\
\hline 12 & 1.33 & $10: 04 \pm 06: 31(07: 38-16: 29)$ & $7 / 9$ & $83.26 \pm 0.13$ & $24.96 \pm 1.57(22.51-26.72)$ & $9 / 9$ & $1.4 \mathrm{E}+04(7.3 \mathrm{E}+04-4,382.9)$ \\
\hline 14 & 2.67 & $07: 01 \pm 00: 17(05: 56-23: 09)$ & $9 / 9$ & $83.47 \pm 0.11$ & $24.113 \pm 5.9738(15.28-31.16)$ & $9 / 9$ & $2.5 \mathrm{E}+04(9 \mathrm{E}+06-225.4)$ \\
\hline 16 & 3.33 & $0: 0: 14: 01 \pm 58(06: 38-07: 37)$ & $9 / 9$ & $83.47 \pm 0.11$ & $35.185 \pm 2.9199(30.38-38.35)$ & $6 / 9$ & $15.3(379.6-1.8)$ \\
\hline
\end{tabular}

${ }^{a}$ The LAMP assay was performed on the crude extracted DNA while the qPCR was carried out using DNA extracted using a commercial kit at different time points. Abbreviations: $\mathrm{T}=$ storage temperature, $\mathrm{dpi}=$ days postinoculation, $\mathrm{DI}=$ disease index, $\mathrm{Tp}=$ time to positive, $\mathrm{Pos}=$ number of positive, Anneal $=$ anneal ing temperature, $\mathrm{Ct}=$ cycle threshold, $\mathrm{SD}=$ standard deviation, $\mathrm{Neg}=$ negative, and $\mathrm{NT}=$ not tested. 
specificity of both LAMP assays. To verify the parameters of both LAMP assays in vivo, we focused on fully ripe nectarine fruit, which were stored at two temperatures reflecting the storage and shelf life conditions of stone fruit.

The LAMP assay for M. fructicola was less sensitive than the LAMP assay for M. laxa. Notwithstanding, on nectarine inoculated with different amounts of M. laxa, the pathogen detection was possible even without visible symptoms. The LAMP results were confirmed using qPCR. The lowest number of cells in all of the Fire Top nectarine inoculated with $M$. fructicola was 259.7 cells (no symptoms visible), giving two positive replicates out of nine with the qPCR and six out of nine with the LAMP assay, which verified the reliability of the assay. In a similar situation, M. laxa ( 73.5 cells) produced fewer positive results with the LAMP assay (one of nine compared with two of nine with the qPCR). In contrast, Amiga nectarine were less susceptible to M. fructicola and M. laxa, with fewer cells quantified and lower symptoms in all of the experiments. The use of the LAMP assay on the Amiga variety confirmed the reliability and effectiveness of the LAMP assays on the detection of few cells ( 22.8 cells and even 1.3 cells) independent of the nectarine variety, suggesting that the assay is potentially a powerful tool for presymptomatic detection.

According to the natural disease development, a consistent and constant increase in the number of pathogen cells was expected over time; however, in some cases, the pattern of the disease did not correspond to the number of cells shown. In particular, when the whole fruit showed brown rot or the fruit were mummified, the numbers of cells were not the highest ones. This could be explained by the high amount of fungal DNA present in the sample, especially in the mummified fruit, which could inhibit the qPCR. However, the LAMP assay reliably detected the pathogen even in these cases.

On the other hand, the LAMP assays were able to detect the presence of the pathogen even without visible symptoms, when the qPCR did not produce positive results. In summary, both LAMP assays were validated and could be reliably used for the detection of $M$. fructicola and M. laxa. Despite the use of a crude extraction method instead of a commercial and complex DNA extraction used for the qPCR assay, the results of the LAMP assay were consistent, and no inhibition or loss of sensitivity were reported, taking into consideration the likelihood ratios, which were similar to those of the qPCR for both pathogens. The monitoring performed during four winter seasons suggested a higher adaptability of $M$. fructicola, compared with M. laxa, in the Italian orchards. The LAMP assays allow a faster identification in orchard of Monilinia spp., helping the growers to speed the decision-making process about crop protection strategies to be used in the following growing season.

\section{Literature Cited}

Altman, D. G., and Bland, J. M. 1994. Diagnostic tests 2: Predictive values. BMJ 309:102.

Amaral Carneiro, G., Matic, S., Ortu, G., Garibaldi, A., Spadaro, D., and Gullino, M. L. 2017. Development and validation of a TaqMan real time PCR assay for the specific detection and quantification of Fusarium fujikuroi in rice plants and seeds. Phytopathology 107:885-892.

Banani, H., Spadaro, D., Zhang, D., Matic, S., Garibaldi, A., and Gullino, M. L. 2015. Postharvest application of a novel chitinase cloned from Metschnikowia fructicola and overexpressed in Pichia pastoris to control brown rot of peaches. Int. J. Food Microbiol. 199:54-61.

Batra, L. R. 1991. World Species of Monilinia (Fungi): Their Ecology, Biosystematics and Control. Mycologia Memoir No. 16. J. Cramer, ed. Koeltx Botanical Books, Berlin, Germany.

Boehm, E. W. A., Ma, Z., and Michailides, T. J. 2001. Species-specific detection of Monilinia fructicola from California stone fruits and flowers. Phytopathology 91:428-439.

Byrde, R. J. W., and Willetts, H. J. 1977. The Brown Rot Fungi of Fruit. Pergamon Press, London, U.K.

Chen, F., Liu, X., and Schnabel, G. 2013. Field strains of Monilinia fructicola resistant to both MBC and DMI fungicides isolates from stone fruit orchards in the Eastern United States. Plant Dis. 97: 1063-1068.

Chomczynski, P., and Rymaszewski, M. 2006. Alkaline polyethylene glycolbased method for direct PCR from bacteria, eukaryotic tissue samples, and whole blood. Biotechniques 40:454-458.
Côté, M.-J., Tardif, M. C. C., Meldrum, A. J., Cote, M. J., Tardif, M. C. C., and Meldrum, A. J. 2004. Identification of Monilinia fructigena, M. fructicola, M. laxa and Monilia polystroma on inoculated and naturally infected fruit using multiplex PCR. Plant Dis. 88:1219-1225.

Cox, K. D., Villani, S. M., Poniatowska, A., Schnabel, G., Holb, I., and Fajardo, J. 2018. Recovery plan for Monilinia polystroma causing Asiatic brown rot of stone fruits. Plant Health Prog. 19:107-124. doi:10.1094/PHP-12-17-0080-RP

Cox, K. D., Villani, S. M., Raes, J. J., Freier, J., Faubert, H., Cooley, D., and Clements, J. 2011. First reports of brown fruit rot on sweet cherry (Prunus avium) and plum $(P$. domestica), and shoot blight on apricot $(P$. armenica), kwanzan cherry $(P$. serrulata) and sweet cherry $(P$. avium $)$ caused by Monilinia laxa in New York, Rhode Island and Massachusetts. Plant Dis. 95: 1584.

De Cal, A., Gell, I., Usall, J., Viñas, I., and Melgarejo, P. 2009. First report of brown rot caused by Monilinia fructicola in peach orchards in Ebro Valley, Spain. Plant Dis. 93:763.

Di Francesco, A., Fruk, M., Martini, C., Jemric, T., and Mari, M. 2015. First report of Asiatic brown rot (Monilinia polystroma) on apple in Croatia. Plant Dis. 99: 1181.

Eckert, J. W., and Ogawa, J. M. 1988. The chemical control of postharvest diseases: Deciduous fruits, berries, vegetables and root/tuber crops. Annu. Rev. Phytopathol. 26:433-469.

EFSA PLH. 2011. Pest risk assessment of Monilinia fructicola for the EU territory and identification and evaluation of risk management options 1. EFSA J. 9 2119. http://www.efsa.europa.eu/en/efsajournal/doc/2119.pdf

Egüen, B., Melgarejo, P., and De Cal, A. 2016. The effect of fungicide resistance of the structure of Monilinia laxa populations in Spanish peach and nectarine orchards. Eur. J. Plant Pathol. 145:815-827.

Franco Ortega, S., Tomlinson, J., Gilardi, G., Spadaro, D., Gullino, M. L. Garibaldi, A., and Boonham, N. 2018a. Rapid detection of Fusarium oxysporum f. sp. lactucae on soil, lettuce seeds and plants using loopmediated isothermal amplification. Plant Pathol. 67:1462-1473.

Franco Ortega, S., Tomlinson, J., Hodgetts, J., Spadaro, D., Gullino, M. L., and Boonham, N. 2018b. Development of loop-mediated isothermal amplification assays for the detection of seedborne fungal pathogens, Fusarium fujikuroi and Magnaporthe oryzae, in rice seeds. Plant Dis. 102:1549-1558.

Gell, I., Cubero, J., and Melgarejo, P. 2007. Two different PCR approaches for universal diagnosis of brown rot and identification of Monilinia spp. in stone fruit trees. J. Appl. Microbiol. 103:2629-2637.

Guinet, C., Fourrier-Jeandel, C., Cerf-Wendling, I., and Ioos, R. 2016. One-step detection of Monilinia fructicola, M. fructigena, and M. laxa on Prunus and Malus by a multiplex real-time PCR assay. Plant Dis. 100:2465-2474.

Harvey, J. M. 1978. Reduction of losses in fresh market fruits and vegetables. Annu. Rev. Phytopathol. 16:321-341.

Hilber-Bodmer, M., Knorst, V., Smits, T. H. M., and Patocchi, A. 2012. First report of Asian brown rot caused by Monilinia polystroma on apricot in Switzerland. Plant Dis. 96:146.

Hinrichs-Berger, J., and Müller, G. 2010. First record of Monilia fructicola on blackberry fruits. J. Plant Dis. Prot. 117:110-111.

Hong, C., Holtz, B. A., Morgan, D. P., and Michailides, T. J. 1997. Significance of thinned fruit as a source of the secondary inoculum of Monilinia fructicola in California nectarine orchards. Plant Dis. 81:519-524

Hong, C., Michailides, T. J., and Holtz, B. A. 1998. Effects of wounding, inoculum density, and biological control agents on postharvest brown rot of stone fruits. Plant Dis. 82:1210-1216.

Hughes, K. J. D., Fulton, C. E., McReynolds, D., and Lane, C. R. 2000 Development of new PCR primers for identification of Monilinia species. Bull. OEPP/EPPO Bull. 30:507-511.

Ioos, R., and Frey, P. 2000. Genomic variation within Monilinia laxa, M fructigena and M. fructicola and application to species identification by PCR Eur. J. Plant Pathol. 106:373-378.

Lane, C. R. 2002. A synoptic key for differentiation of Monilinia fructicola, $M$. fructigena and $M$. laxa, based on examination of cultural characters. Bull. OEPP/EPPO Bull. 32:489-493.

Larena, I., Torres, R., De Cal, A., Liñan, M., Melgarejo, P., Domenichini, P., Bellini, A., Mandrin, J. F., Lichou, J., Ochoa de Eribe, X., and Usall, J. 2005 Biological control of postharvest brown rot (Monilinia spp.) of peaches by field applications of Epicoccum nigrum. 2005. Biol. Control 32:305-310.

Lichou, J., Mandrin, J. F., Breniaux, D., Mercier, V., Giauque, P., Desbrus, D. Blanc, P., and Belluau, E. 2002. Une nouvelle moniliose. Phytoma 547:22-25.

Lopez-Reyes, J. G., Spadaro, D., Prelle, A., Garibaldi, A., and Gullino, M. L. 2013. Efficacy of plant essential oils on postharvest control of rots caused by fungi on different stone fruits in vivo. J. Food Prot. 76:631-639.

Luo, C. X., Hu, M. J., Jin, X., Yin, L. F., Bryson, P. K., and Schnabel, G. 2010. An intron in the cytochrome $\mathrm{b}$ gene of Monilinia fructicola mitigates the risk of resistance development to QoI fungicides. Pest Manage. Sci. 66:1308-1315.

Luo, Y., and Michailides, T. J. 2001a. Factors affecting latent infection of prune fruit by Monilinia fructicola. Phytopathology 91:864-872.

Luo, Y., and Michailides, T. J. 2001b. Risk analysis for latent infection of prune by Monilinia fructicola in California. Phytopathology 91:1197-1208.

Luo, Y., Morgan, D. P., and Michailides, T. J. 2001. Risk analysis of brown rot blossom blight of prune caused by Monilinia fructicola. Phytopathology 91: 759-768 
Ma, Z. Z., Luo, Y. Y. L., and Michailides, T. J. 2003. Nested PCR assays for detection of Monilinia fructicola in stone fruit orchards and Botryosphaeria dothidea from pistachios in California. J. Phytopathol. 151:312-322.

Margosan, D. A., Smilanick, J. L., Simmons, G. F., and Henson, D. J. 1997. Combination of hot water and ethanol to control postharvest decay of peaches and nectarines. Plant Dis. 81:1405-1409.

Mari, M., Leoni, O., Bernardi, R., Neri, F., and Palmieri, S. 2008. Control of brown rot on stone fruit by synthetic and glucosinolate-derived isothiocyanates. Postharvest Biol. Technol. 47:61-67.

Mari, M., Martini, C., Guidarelli, M. N., and Neri, F. 2012. Postharvest biocontrol of Monilinia laxa, Monilinia fructicola and Monilinia fructigena on stone fruit by two Aureobasidium pullulans strains. Biol. Control 60:132-140.

Martini, C., Lantos, A., Di Francesco, A., Guidarelli, M., D’Aquino, S., and Baraldi, E. 2014. First report of Asiatic brown rot caused by Monilinia polystroma on peach in Italy. Plant Dis. 98:1585.

Martini, C., and Mari, M. 2014. Monilinia fructicola, Monilinia laxa (Monilinia rot, Brown rot). Pages 233-265 in: Postharvest Decay: Control Strategies. S. Bautista-Baños, ed. Academic Press, London, U.K.

Munda, A., and Viršček Marn, M. 2010. First report of brown rot caused by Monilinia fructicola affecting peach orchards in Slovenia. Plant Dis. 94:1166.

Nagamine, K., Hase, T., and Notomi, T. 2002. Accelerated reaction by loopmediated isothermal amplification using loop primers. Mol. Cell. Probes 16: 223-229.

Notomi, T., Okayama, H., Masubuchi, H., Yonekawa, T., Watanabe, K., Amino, N., and Hase, T. 2000. Loop-mediated isothermal amplification of DNA. Nucleic Acids Res. 28:e63.

OEPP/EPPO. 2002. Monilinia fructicola found in Austria. EPPO Rep. Serv. 11: Article 2002/170. https://gd.eppo.int/reporting/article-2334

OEPP/EPPO. 2009. PM 7/18(2): Monilinia fructicola. Bull. OEPP/EPPO Bull. 39: 337-343.

Pellegrino, C., Gullino, M. L., Garibaldi, A., and Spadaro, D. 2009. First report of brown rot of stone fruit caused by Monilinia fructicola in Italy. Plant Dis. 93: 668

Petróczy, M., and Palkovics, L. 2009. First report of Monilia polystroma on apple in Hungary. Eur. J. Plant Pathol. 125:343-347.

Poniatowska, A., Michalecka, M., and Bielenin, A. 2013. Characteristic of Monilinia spp. fungi causing brown rot of pome and stone fruits in Poland. Eur. J. Plant Pathol. 135:855-865.
Santoro, K., Maghenzani, M., Chiabrando, V., Bosio, P., Gullino, M. L., Spadaro, D., and Giacalone, G. 2018. Thyme and savory essential oil vapor treatments control brown rot and improve the storage quality of peaches and nectarines, but could favor gray mold. Foods 7:7.

Smith, I. M., McNamara, D. G., Scott, P. R., and Holderness, M., eds. 1997. Monilinia fructicola. Pages 530-535 in: Quarantine Pests for Europe, 2nd ed. CAB International, Wallingford, U.K.

Spadaro, D., and Droby, S. 2016. Development of biocontrol products for postharvest diseases of fruit: The importance of elucidating the mechanisms of action of yeast antagonists. Trends Food Sci. Technol. 47:39-49.

Tate, K. G., and Wood, P. N. 2000. Potential ascospore production and resulting blossom blight by Monilinia fructicola in unsprayed peach trees. N. Z. J. Crop Hortic. Sci. 28:219-224.

Thomidis, T., Michailides, T., and Exadaktylou, E. 2009. Contribution of pathogens to peach fruit rot in northern Greece and their sensitivity to iprodione, carbendazim, thiophanate-methyl and tebuconazole fungicides. J. Phytopathol. 157:194-200.

Tomlinson, J. A., Boonham, N., and Dickinson, M. 2010a. Development and evaluation of a one-hour DNA extraction and loop-mediated isothermal amplification assay for rapid detection of phytoplasmas. Plant Pathol. 59:465-471.

Tomlinson, J. A., Dickinson, M. J., and Boonham, N. 2010b. Rapid detection of Phytophthora ramorum and P. kernoviae by two-minute DNA extraction followed by isothermal amplification and amplicon detection by generic lateral flow device. Phytopathology 100:143-149.

Van Brouwershaven, I. R., Bruil, M. L., Van Leeuwen, G. C. M., and Kox, L. F. F. 2009. A real-time (TaqMan) PCR assay to differentiate Monilinia fructicola from other brown rot fungi of fruit crops. Plant Pathol. 59:548-555.

Villarino, M., Egüen, B., Lamarca, N., Segarra, J., Usall, J., Melgarejo, P., and De Cal, A. 2013. Occurrence of Monilinia laxa and M. fructigena after introduction of M. fructicola in peach orchards in Spain. Eur. J. Plant Pathol. 137:835-845.

Wang, J.-R., Guo, L.-Y., Xiao, C.-L., and Zhi, X. 2018. Detection and identification of six Monilinia spp. causing brown rot using Taqman realtime PCR from pure cultures and infected apple fruit. Plant Dis. 102:1527-1533.

Wilson, I. G. 1997. Inhibition and facilitation of nucleic acid amplification. Appl. Environ. Microbiol. 63:3741-3751.

Zhang, D., Spadaro, D., Garibaldi, A., and Gullino, M. L. 2010. Selection and evaluation of new antagonists for their efficacy against postharvest brown rot of peaches. Postharvest Biol. Technol. 55:174-181. 